\title{
Aircraft observations and model simulations of concentration and particle size distribution in the Eyjafjallajökull volcanic ash cloud
}

\author{
H. F. Dacre ${ }^{1}$, A. L. M. Grant ${ }^{1}$, and B. T. Johnson ${ }^{2}$ \\ ${ }^{1}$ Department of Meteorology, University of Reading, Reading, UK \\ ${ }^{2}$ Met Office, Exeter, UK
}

Correspondence to: H. F. Dacre (h.f.dacre@ reading.ac.uk)

Received: 26 July 2012 - Published in Atmos. Chem. Phys. Discuss.: 3 September 2012

Revised: 30 November 2012 - Accepted: 6 December 2012 - Published: 1 February 2013

\begin{abstract}
The Eyjafjallajökull volcano in Iceland emitted a cloud of ash into the atmosphere during April and May 2010. Over the UK the ash cloud was observed by the FAAM BAe146 Atmospheric Research Aircraft which was equipped with in-situ probes measuring the concentration of volcanic ash carried by particles of varying sizes. The UK Met Office Numerical Atmospheric-dispersion Modelling Environment (NAME) has been used to simulate the evolution of the ash cloud emitted by the Eyjafjallajökull volcano during the period 4-18 May 2010. In the NAME simulations the processes controlling the evolution of the concentration and particle size distribution include sedimentation and deposition of particles, horizontal dispersion and vertical wind shear. For travel times between 24 and $72 \mathrm{~h}$, a $1 / t$ relationship describes the evolution of the concentration at the centre of the ash cloud and the particle size distribution remains fairly constant. Although NAME does not represent the effects of microphysical processes, it can capture the observed decrease in concentration with travel time in this period. This suggests that, for this eruption, microphysical processes play a small role in determining the evolution of the distal ash cloud. Quantitative comparison with observations shows that NAME can simulate the observed column-integrated mass if around $4 \%$ of the total emitted mass is assumed to be transported as far as the UK by small particles $(<30 \mu \mathrm{m}$ diameter). NAME can also simulate the observed particle size distribution if a distal particle size distribution that contains a large fraction of $<10 \mu \mathrm{m}$ diameter particles is used, consistent with the idea that phraetomagmatic volcanoes, such as Eyjafjallajökull, emit very fine particles.
\end{abstract}

\section{Introduction}

The 2010 Eyjafjallajökull volcanic eruption affected air traffic over Europe for 13 days, leaving 10 million passengers stranded and leading to an estimated revenue loss of $£ 1.5$ billion to the airline industry due to the closure of European air space (European Commission, 2010). Thus, accurate predictions of the evolution of volcanic ash clouds are important for the airline and tourist industries as well as policy makers and the general public. The aims of this paper are to evaluate model simulations of volcanic ash using in-situ measurements, to develop a new method for estimating the distal particle size distribution, and to explain the general dispersion characteristics of volcanic ash particles.

The characterisation of volcanic eruption source parameters such as the mass eruption rate and particle size distribution are crucial for accurately predicting volcanic ash dispersion. In this paper particles are defined as the entities dispersing in the atmosphere, which may be either unaggregated single grains of ash or aggregates, i.e. clusters of grains of ash. Most volcanic ash dispersion models do not represent the complex microphysical processes which occur close to the volcano. Therefore, it is necessary to assume an effective "distal" source describing the mass and characteristics of material remaining in the ash cloud after these processes have occurred. In this paper distal refers to parcicles $>500 \mathrm{~km}$ or $>6 \mathrm{~h}$ travel time from the volcano and near-source refers to particles $<500 \mathrm{~km}$ or $<6 \mathrm{~h}$ travel time from the volcano. At present, methods exist for estimating the total mass eruption rate and particle size distribution. For example, as there is no direct method of measuring the mass eruption rate of erupting volcanoes, most volcanic ash dispersion models use 
empirical relationships to relate observed maximum plume height to the total mass eruption rate (Wilson et al., 1978; Sparks et al., 1997; Mastin et al., 2009). However, the fraction of the total emitted mass that remains in the distal ash cloud (i.e. carried by small ash particles that have not fallen out close to the source) is not well known. Similarly, methods to estimate particle size distribution are frequently based on analysis of ash deposits close to the volcano vent, as distal ash is often too widely dispersed to be sampled (Volentik et al., 2010; Rust and Cashman, 2011). Thus, these calculated particle size distributions, based on fall deposits, are representative of the near-source particle size distribution only. In addition, they are not available in real time and can depend strongly on the method used to analyse the deposits (Bonadonna and Houghton, 2005). In this paper we compare NAME simulations with in-situ observations of ash concentrations and particle size distributions (PSD) in the distal ash cloud with a view to determining the distal fine ash fraction (DFAF) and distal particle size distribution (DPSD). The $D F A F$ is defined as the fraction of the total emitted mass, carried by small particles $(<30 \mu$ m diameter) that remains in the distal ash cloud. The DPSD is defined as the the size distribution of the particles remaining in the distal ash cloud.

The characterisation of distal eruption source parameters is crucial for volcanic ash dispersion models, as studies have shown that for individual cases, variations in the assumed PSD can lead to dramatic variations in tephra dispersion results (Daniele et al., 2009; Scollo et al., 2008). Similarly, varying the DFAF simply scales the modelled ash concentrations. It is possible that these distal eruption source parameters may vary in time. For example, Kratzmann et al. (2010) suggested that the highly stratified nature of fall deposits they observed (fine ash layered with pumice lapilli) was likely to be the result of multiple events leading to variations in the dominant particle size being deposited. Other studies suggest that differential sedimentation and subsequent deposition of particles can lead to variations in the near-source observations. For example, Scasso et al. (1994) found that the mean and median particle sizes deposited at the surface from the Hudson volcano decreased rapidly up to $270 \mathrm{~km}$ from the volcano vent, beyond that point they were more or less constant up to $550 \mathrm{~km}$. Similarly, in a study combining ash fallout data observed up to $100 \mathrm{~km}$ from the volcano, for a range of volcanic eruptions, Horwell (2007) found that there was a strong linear relationship between $4 \mu \mathrm{m}$ and $10 \mu \mathrm{m}$ ash particles but a weaker non-linear relationship between $4 \mu \mathrm{m}$ and $63 \mu \mathrm{m}$ fractions. Both these results show that the coarse mode in the PSD shifts to finer sizes with distance from the volcano in the near-source region. However, the equivalent relationships at distances greater than $500 \mathrm{~km}$ have not been studied. Furthermore, Horwell (2007) suggests that the effect of wind shear can result in particles of different diameters being transported in different directions. Similarly, aggregation processes, which may be size dependent, may affect the column-integrated mass and PSD. High water con- tent and electrostatic charging are believed to enhance deposition through particle aggregation (Ilyinskaya et al., 2011). In this paper we will determine the factors controlling the variability in concentration and PSD in the distal ash cloud.

\section{NAME simulations}

NAME is a Lagrangian particle trajectory model designed for many dispersion applications, including the prediction of the dispersion and deposition of volcanic ash in the atmosphere (Jones et al., 2007). Emission of volcanic ash is modelled by releasing ash particles into the model atmosphere, with each particle representing a mass of volcanic ash. The model ash particles are carried along by the wind with turbulent mixing represented by giving the trajectories a stochastic perturbation using semi-empirical turbulence profiles. NAME also includes treatments of sedimentation and dry and wet deposition (see Dacre et al., 2011, and Webster et al., 2012, for further details).

In this paper, NAME III (version 6.0) is driven using the 3-D winds and thermodynamic fields from the UK Met Office global numerical weather prediction model analysis fields, updated every $6 \mathrm{~h}$ and forecast fields updated every $3 \mathrm{~h}$. Ash concentrations are computed by summing the mass of ash particles in areas of $0.375^{\circ}$ latitude by $0.5625^{\circ}$ longitude, averaged over $200 \mathrm{~m}$ in the vertical and over a time period of $1 \mathrm{~h}$. Plume height input is taken from measurements provided by the Icelandic Meteorological Office's Cband radar (Arason et al., 2011), and ash is emitted over the top $1 \mathrm{~km}$ only. However, it should be noted that Stohl et al. (2011) found, using an inversion method, that the temporal evolution of the plume height may be significantly different from the radar observed values. All of the emitted mass in NAME is distributed among particles with a diameter drawn from DPSD 1, shown in Table 1. This distribution is based on an average of measurements made in the plumes from explosive eruptions of Mount Redoubt on 8 January 1990, Mount St. Helens on 18 May 1980, and St. Augustine on 8 February 1976 (Hobbs et al., 1991; Leadbetter and Hort, 2011). The ash density in NAME is assumed to be $2300 \mathrm{~kg} \mathrm{~m}^{-3}$.

\section{Aircraft observations}

Over Europe, the ash cloud from Eyjafjallajökull was observed by the Facility for Airborne Atmospheric Measurements (FAAM) BAe-146 aircraft. The aircraft was equipped with in-situ particle measuring probes including a Cloud Aerosol Precipitation Spectrometer (CAPS) probe operated by the University of Manchester. The Cloud Aerosol Spectrometer (CAS) component of CAPS was used to derive ash particle size distributions and mass concentrations. The CAS is a forward scattering (4-12 degrees) optical particle counter that measures particles in the nominal diameter range 0.6$50 \mu \mathrm{m}$. Johnson et al. (2012) showed that the size distribution 
Table 1. Distal particle size distributions (DPSDs). DPSDs 1, 2 and 3 are used as input to the NAME model. Other DPSDs are derived from observations on 5, 14 and 17 May 2010.

\begin{tabular}{|c|c|c|c|c|c|c|}
\hline & $\begin{array}{r}\text { Original } \\
\text { (DPSD 1) }\end{array}$ & $\begin{array}{l}5 \text { May } \\
\text { DPSD }\end{array}$ & $\begin{array}{r}14 \text { May } \\
\text { DPSD }\end{array}$ & $\begin{array}{r}17 \text { May } \\
\text { DPSD }\end{array}$ & $\begin{array}{r}\text { Average } \\
\text { (DPSD 2) }\end{array}$ & $\begin{array}{r}\text { Uniform } \\
\text { (DPSD 3) }\end{array}$ \\
\hline $\begin{array}{r}\text { Particle diameter } \\
(\mu \mathrm{m})\end{array}$ & $\begin{array}{r}\text { Fraction of mass } \\
(\%)\end{array}$ & $\begin{array}{r}\text { Fraction of mass } \\
(\%)\end{array}$ & $\begin{array}{r}\text { Fraction of mass } \\
(\%)\end{array}$ & $\begin{array}{r}\text { Fraction of mass } \\
(\%)\end{array}$ & $\begin{array}{r}\text { Fraction of mass } \\
(\%)\end{array}$ & $\begin{array}{r}\text { Fraction of mass } \\
(\%)\end{array}$ \\
\hline $0.1-0.3$ & 0.1 & - & - & - & 0.0 & 16.7 \\
\hline $0.3-1.0$ & 0.5 & 0.7 & 0.6 & 0.9 & 0.7 & 16.7 \\
\hline $1.0-3.0$ & 5.0 & 29.5 & 23.5 & 41.4 & 31.4 & 16.7 \\
\hline $3.0-10.0$ & 20.0 & 68.6 & 53.5 & 54.6 & 58.9 & 16.7 \\
\hline $10.0-30.0$ & 70.0 & 1.2 & 22.5 & 3.2 & 9.0 & 16.7 \\
\hline $30.0-100.0$ & 4.4 & - & - & - & 0.0 & 16.7 \\
\hline
\end{tabular}

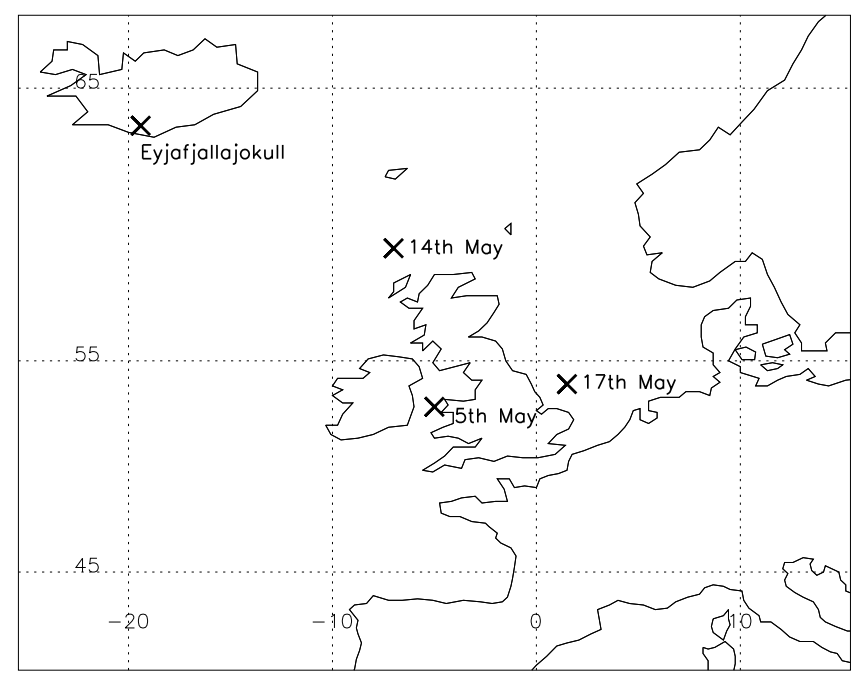

Fig. 1. Location of FAAM aircraft profiles in relation to Eyjafjallajökull volcano vent.

of ash particles from the Eyjafjallajökull eruption was typically $0.6-35 \mu \mathrm{m}$, and as such the mass concentration could be estimated, to within a factor of two, based on the CAS instrument. Figure 1 shows the locations of three vertical profiles performed by the FAAM aircraft at 12:40 UTC on 5 May, 12:43 UTC on 14 May and 14:52 UTC on 17 May 2010 in relation to the Eyjafjallajökull volcano vent. Each of these profiles intersected a distinct ash layer that was free from water or ice clouds and well above the planetary boundary layer such that the aerosol mass was dominated by ash particles (Johnson et al., 2012).

\subsection{Observed particle size distributions}

Figure 2a shows the observed column-integrated PSDs measured on the FAAM aircraft. Both the magnitude and the shape of the distributions vary depending on the specific time and location at which the observations were taken. The column-integrated mass loadings calculated from the
CAS mass profiles were $197 \mathrm{mg} \mathrm{m}^{-2}, 969 \mathrm{mg} \mathrm{m}^{-2}$ and $1211 \mathrm{mg} \mathrm{m}^{-2}$ on 5,14 and 17 May, respectively. All of the PSDs have their mode at approximately $4 \mu \mathrm{m}$, but the shape of the distributions varies. Figure $2 \mathrm{~b}$ shows that on 5 and 14 May the percentage of the column-integrated mass carried by particles with diameters less than $4 \mu \mathrm{m}$ is very similar (35\%), but the percentage carried by particles with diameters greater than $10 \mu \mathrm{m}$ is much larger on the 14 th than on the 5th $(20 \%$ compared to $5 \%$ ). On 17 May the particle size distribution contains mainly fine ash, with $60 \%$ of the column-integrated mass carried by particles with diameters less than $4 \mu \mathrm{m}$ and less than $5 \%$ carried by particles with diameters greater than $10 \mu \mathrm{m}$. The Aerosol Research Lidar Network (EARLINET) and Aerosol Robotic Network (AERONET) sun photometer observations of volcanic aerosol taken at Cabauw, Netherlands, and Hamburg, Munich and Leipzig, Germany, during April and May 2010 (Ansmann et al., 2011) also have PSDs with a coarse mode between 1 and $3 \mu \mathrm{m}$.

The aircraft observations provide an excellent opportunity to evaluate volcanic ash transport and dispersion models and to test the sensitivity of the simulated ash cloud to assumptions about the distal eruption source parameters. First it is important to determine whether NAME can simulate column-integrated masses and PSDs that are consistent with the observations. If so, we can then use the NAME simulations to determine what controls the variability in both the column-integrated mass and the column-integrated PSDs seen in the observations.

\subsection{Ash concentration profiles}

When performing a quantitative comparison between the column-integrated quantities in the NAME simulations and the aircraft observations, it is important to ensure that the column-integrated quantities are calculated over an appropriate depth of the atmosphere. Figure 3 shows the vertical profiles of volcanic ash as measured by the FAAM aircraft and simulated by NAME at 12:00 UTC on 5 May, 13:00 UTC on 14 May and 15:00 UTC on 17 May. The observed and DPSD 

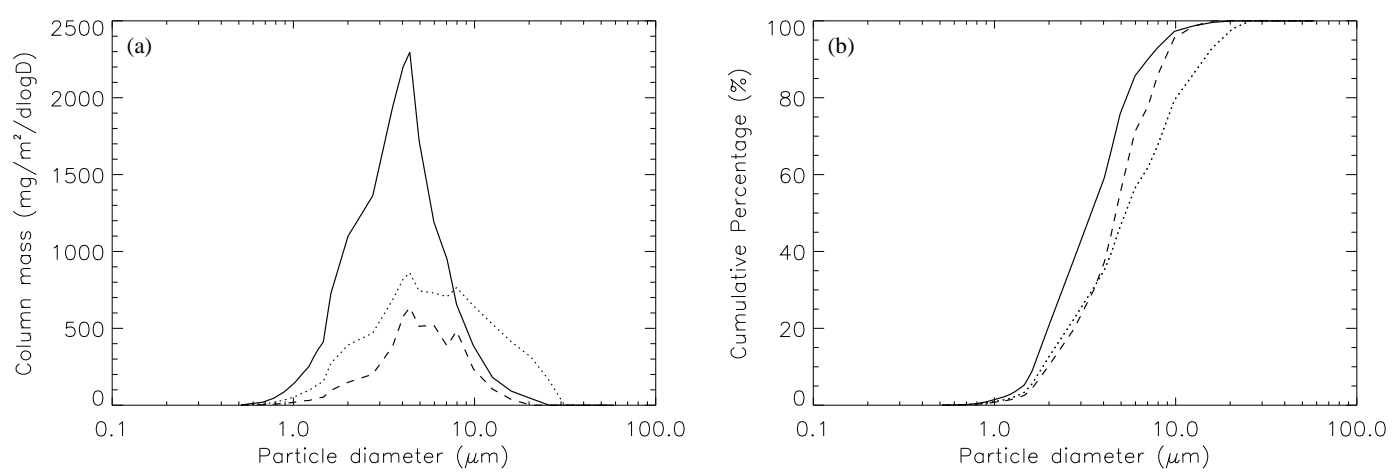

Fig. 2. (a) Observed column-integrated mass and (b) observed column-integrated particle size distribution. 12:00 UTC on 5 May (dashed), 13:00 UTC on 14 May (dotted) and 15:00 UTC on 17 May (solid).
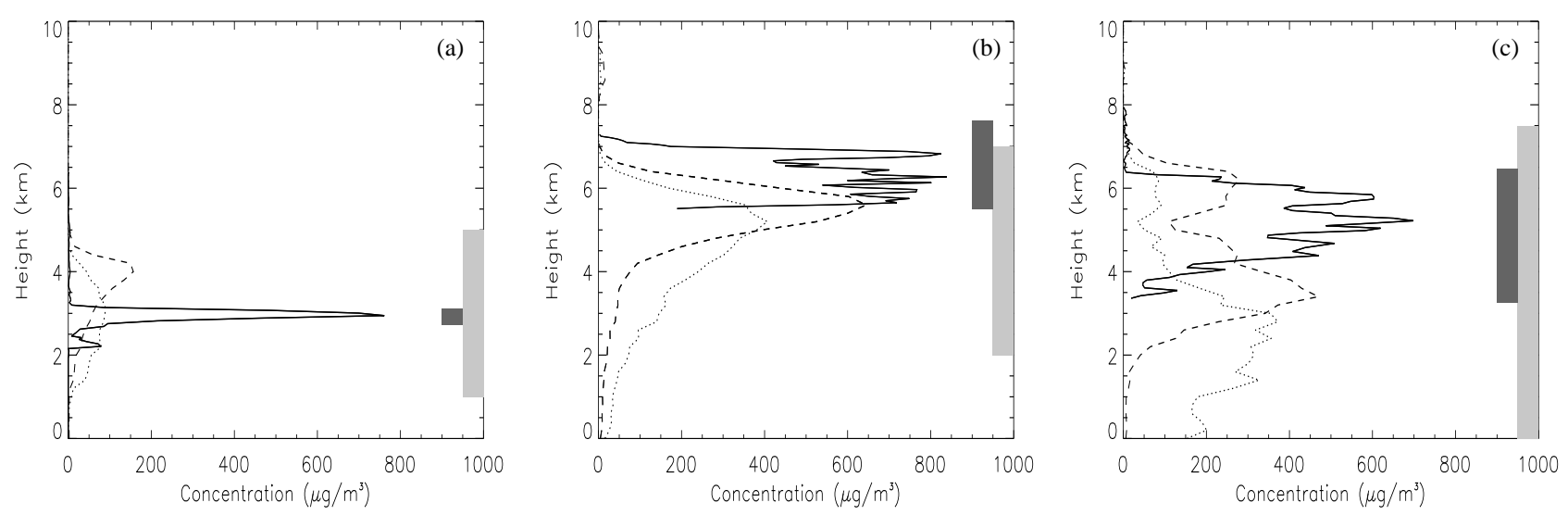

Fig. 3. Concentration profiles for (a) 12:00 UTC on 5 May, (b) 13:00 UTC on 14 May and (c) 15:00 UTC on 17 May. Observations (solid) and NAME simulations using distal particle size distribution 1 (dotted) and 2 (dashed). The dark grey bar shows the height range over which the observed particle size distributions are calculated. The light grey bar shows the height range over which the NAME simulated particle size distributions are calculated.

1 concentration profiles are discussed in this section, and the DPSD 2 concentration profiles are discussed in Sect. 5.3.

On 5 May, Fig. 3a, the ash cloud was observed at an altitude of $3 \mathrm{~km}$ and in a very thin layer of less than $1 \mathrm{~km}$ depth. The FAAM aircraft performed an ascent between $250 \mathrm{~m}$ and $6390 \mathrm{~m}$ above sea level. However, the columnintegrated mass and particle size distribution, Fig. 2a, was only calculated over the part of the profile where there was a clearly defined ash layer (to minimise contamination of the size distribution with boundary layer or other background aerosol). This layer was between $2730 \mathrm{~m}$ and $3120 \mathrm{~m}$. Therefore, when comparing the observed and NAME simulated column-integrated mass and PSD, the NAME quantities should also only be calculated over the part of the profile where there is a clearly defined ash layer. Figure $3 \mathrm{a}$ also shows the ash layer from the NAME simulation using DPSD 1. A clearly defined layer of ash is simulated extending between 1 and $4.5 \mathrm{~km}$. This layer is used to calculate the PSD and column-integrated mass.
On 14 May, Fig. 3b, the ash layer was observed between 5.5 and $7.5 \mathrm{~km}$. The FAAM aircraft performed a descent between $7310 \mathrm{~m}$ and $5490 \mathrm{~m}$ a.s.l. The column-integrated mass and PSD, Fig. 2a, were calculated over the entire depth of the profile. Figure $3 b$ also shows the ash layer from the NAME simulation using DPSD 1. A clearly defined layer of ash is simulated extending in a broad layer between 1.5 and $6.5 \mathrm{~km}$ and a second, lower concentration layer between 7.5 and $9.5 \mathrm{~km}$. The FAAM aircraft did not take measurements above $7.3 \mathrm{~km}$ on this flight. Therefore, the existence of this upperlayer cannot be verified and only the layer between 1.5 and $6.5 \mathrm{~km}$ is used to calculate the PSD and column-integrated mass.

On 17 May, Fig. 3c, the ash layer was observed in a broad layer between 3.5 and $6.5 \mathrm{~km}$ with peak concentrations at $5.5 \mathrm{~km}$. The FAAM aircraft performed a descent between $7940 \mathrm{~m}$ and $3080 \mathrm{~m}$ a.s.l. However, the column-integrated mass and PSD, Fig. 2a, was only calculated over the part of the profile where there was a clearly defined ash layer, between $6470 \mathrm{~m}$ and $3270 \mathrm{~m}$. Figure $3 \mathrm{c}$ also shows the ash 

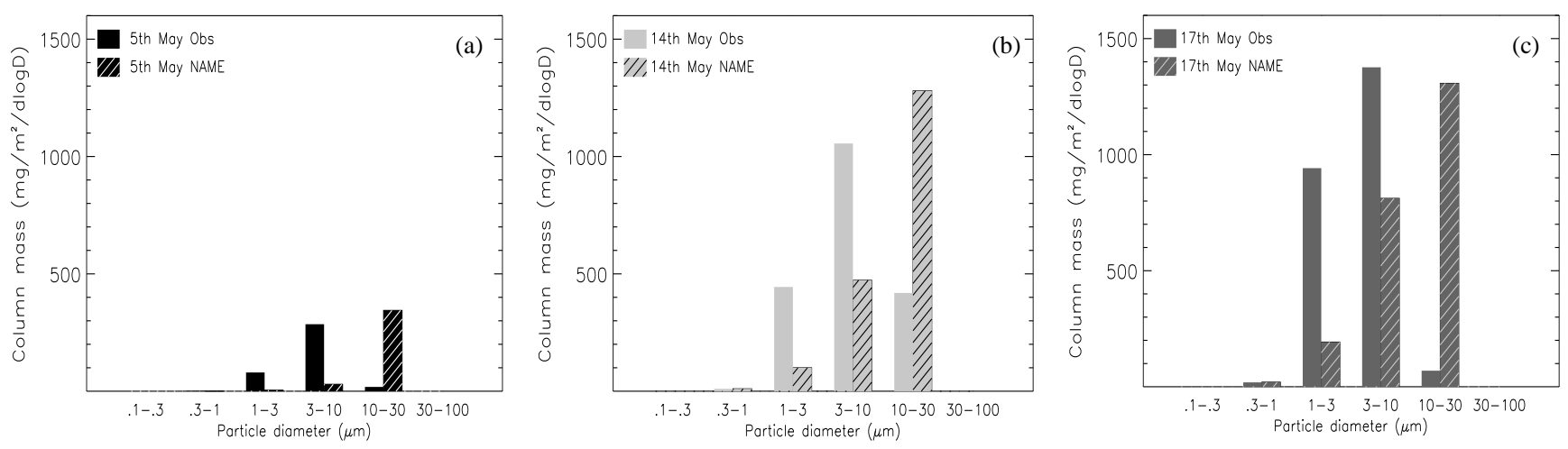

Fig. 4. Binned observed column-integrated mass (solid fill) and NAME column-integrated mass (striped fill) using distal particle size distribution 1. (a) 12:00 UTC on 5 May, (b) 13:00 UTC on 14 May and (c) 15:00 UTC on 17 May.

layer from the NAME simulation using DPSD 1. The NAME simulation has low-levels of ash extending from the surface to $7 \mathrm{~km}$ with peak concentrations occurring at an altitude of $1.5-2.5 \mathrm{~km}$. There is no clearly defined layer of ash in the NAME simulations. In this case the layer from the surface up to $6.5 \mathrm{~km}$ is used to calculate the PSD and column-integrated mass.

\section{Distal eruption source parameters}

As discussed in the introduction, in order to estimate the column-integrated mass in the distal ash cloud, the important number to quantify is the fraction of total emitted mass that remains in the ash cloud after sedimentation of large particles and near-source microphysical processes have occurred. This distal fine ash fraction (DFAF) is used as a scaling factor that is applied to the model amounts to allow quantitative predictions of ash concentration at long range.

\subsection{Distal fine ash fraction}

The distal fine ash fraction (DFAF) is defined as the fraction of the total emitted mass remaining in the distal ash cloud. In order to estimate the DFAF, the ratio of the NAME columnintegrated mass, calculated over the depths determined in Sect. 3.2, to the observed column-integrated mass is calculated using the method of Dacre et al. (2011).

On 5 May quantitative agreement between NAME and the observed column-integrated mass is obtained by assuming that the DFAF is $2.1 \%$, i.e. the NAME column-integrated mass matches the observed column-integrated mass if the modelled column-integrated mass is scaled by $2.1 \%$. This suggests that $97.9 \%$ of the total emitted mass falls out close to the source. On 14 May quantitative agreement between NAME and the observed column-integrated mass is obtained by assuming that the DFAF is $2.9 \%$. On 17 May quantitative agreement between NAME and the observed columnintegrated masses is obtained by assuming that the DFAF is
$6.9 \%$. Thus, NAME can simulate column-integrated masses that are consistent with the observations if a DFAF of between 2 and $7 \%$ is used. There are of course uncertainties in these estimates arising from inaccuracies in the modelling. For example, Kaminski et al. (2011) show that mass eruption rates deduced from the height reached by the volcanic plume on the basis of scaling laws inferred from models of powerful Plinian plumes may be overestimated for less explosive basaltic eruptions.

\subsection{Distal particle size distribution}

The distal particle size distribution (DPSD) is the size distribution of the particles remaining in the distal ash cloud. Figure 4 shows the observed column-integrated PSDs on 5, 14 and 17 May binned into particle size bins corresponding to the 6 size bins used in NAME (described in Table 1). The mode of the binned observed column-integrated PSD occurs in the 3.0 and $10.0 \mu \mathrm{m}$ diameter size bin for all three observations. Figure 4 also shows the NAME columnintegrated PSDs on the 5,14 and 17 May at the same locations as their respective observations. The NAME columnintegrated mass has been rescaled to match the corresponding observed column-integrated mass using the DFAFs calculated in Sect. 4.1. For all 3 cases the NAME simulations using DPSD 1 result in a PSD at the observation location which underestimates the mass carried by particles with diameters between 1.0 and $10.0 \mu \mathrm{m}$ and overestimates the mass carried by particles with diameters between 10.0 and $30.0 \mu \mathrm{m}$. This suggests that DPSD 1 contains a larger fraction of particles with diameters greater than $10 \mu \mathrm{m}$ than actually remained in the distal ash cloud from Eyjafjallajökull.

In order to match the shape of the observed columnintegrated PSD in Fig. 4, it is necessary to use modified DPSDs as input for NAME. The measured DPSDs are shown in Fig. 5. For all three cases the measured DPSDs contain a larger percentage of the distal eruption mass in the 1.0 $3.0 \mu \mathrm{m}$ and $3.0-10.0 \mu \mathrm{m}$ diameter size bins and a smaller percentage of the distal eruption mass in the $10.0-30.0 \mu \mathrm{m}$ 


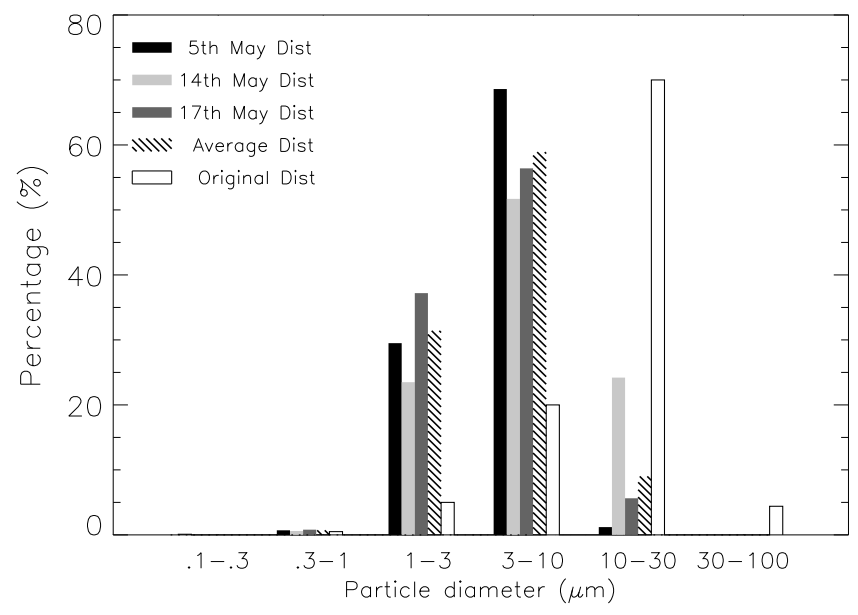

Fig. 5. Distribution of total column mass for distal particle size distribution 1 (white) and derived from observations on 5 May (black), 14 May (light grey) and 17 May (dark grey), and average of observations (striped fill).

diameter size bin. Note, that as there are no observed particles with diameters less than $0.3 \mu \mathrm{m}$ or greater than $30.0 \mu \mathrm{m}$, we therefore assume the mass in these bins is negligible in the distal ash cloud. This redistribution of mass from larger to smaller particle diameter sizes is consistent with the results of Kristiansen et al. (2012), who compared NAME and FLEXPART simulations to observed PSDs. It is also supported by the idea that phraetomagmatic volcanoes, such as Eyjafjallajökull, emit very fine ash particles (Dellino et al., 2011).

Using an average of the 3 measured DPSDs as a modified input DPSD for NAME, i.e. DPSD 2 shown in Table 1, DFAFs of $5.0 \%, 2.6 \%$ and $5.9 \%$ are necessary to match 5 , 14 and 17 May observed column-integrated mass, respectively (Fig. 6). Thus, the calculated DFAF is sensitive to the DPSD used in the model simulation. These DFAFs are consistent with the DFAF found by Dacre et al. (2011) for an earlier stage of the eruption when comparing NAME simulations with ground based lidar observations, and with that found by Grant et al. (2012) when comparing with airborne lidar observations. Figure 6 shows that for all 3 cases there is a much better agreement between the observed and NAME simulated PSDs when using the modified DPSD.

\subsection{Modified ash concentration profiles}

In this section the ash concentration profiles for NAME simulations using DPSDs 1 and 2 are compared to the observed ash concentration profiles.

On 5 May, Fig. 3a, the ash cloud was observed at an altitude of $3 \mathrm{~km}$ and in a very thin layer of less than $1 \mathrm{~km}$ depth. The NAME simulation using DPSD 1 shows a layer of ash extending between 1 and $4.5 \mathrm{~km}$. Although the mean height of the simulated ash cloud agrees with the observations, the
NAME layer is 3 times thicker than the observed layer. Performing the NAME simulation but using DPSD 2 (Fig. 3a) results in a NAME ash layer that exhibits a stronger peak at an altitude of $4 \mathrm{~km}$. There are less large $10-30 \mu \mathrm{m}$ particles in the DPSD, and hence the vertical spreading of the ash cloud due to sedimentation is reduced. The shape of the ash cloud agrees better with the observations, although the peak in concentrations is $1 \mathrm{~km}$ higher. This could be due to errors in the plume height, sedimentation rates or meteorology.

On 14 May, Fig. 3b, the ash layer was observed between 5.5 and $7.5 \mathrm{~km}$. The NAME simulation using DPSD 1 shows a broad layer between 1.5 and $6.5 \mathrm{~km}$ and a second, lower concentration layer between 7.5 and $9.5 \mathrm{~km}$. As for 5 May, the structure of the ash layer becomes more peaked when DPSD 2 is used and the height of the peak concentrations shifts upwards by approximately $1 \mathrm{~km}$. The resultant vertical distribution agrees better with the observations, suggesting that DPSD 1 contains too large a fraction of heavy particles.

Finally, Fig. 3c shows the ash layer on 17 May. Ash was observed between 3.5 and $6.5 \mathrm{~km}$ with peak concentrations at $5.5 \mathrm{~km}$. The NAME simulation using DPSD 1 has low-levels of ash throughout the depth of the troposphere with peak concentrations occurring at an altitude of $2-2.5 \mathrm{~km}$. The simulation using DPSD 2 shifts the low-level peak up by approximately $1 \mathrm{~km}$. The upper-level peak does not change altitude, suggesting that it consists predominately of small particles.

Changing from DPSD 1 to DPSD 2 makes the ash layers thinner, more peaked and higher in altitude by approximately $1 \mathrm{~km}$. However, the peak concentrations can be above or below the observed peak by $1 \mathrm{~km}$, reflecting the uncertainty in the plume height used in the simulations.

To summarise, NAME can simulate column-integrated masses and PSDs that are consistent with the observations if a suitable DFAF and DPSD is used. In the remainder of the paper we use the NAME simulations to investigate what controls the spatial and temporal variability of the columnintegrated mass and PSD. For the remainder of this paper DPSD 2 and a DFAF of $4.5 \%$ are used in the NAME simulations.

\section{Column-integrated mass}

In this section we analyse the spatial and temporal variability of the column-integrated mass. First we analyse the three cases for which we have in-situ observations, then we use the NAME simulations to make more general conclusions.

\subsection{Horizontal variability in column-integrated mass}

Figure 7 shows the ash cloud as measured by the Infrared Atmospheric Sounding Interferometer (IASI) on board METOP-A and the ash cloud simulated by NAME on 5, 14 and 17 May, respectively. Volcanic ash has a very specific infrared signature, which makes it differentiable from 

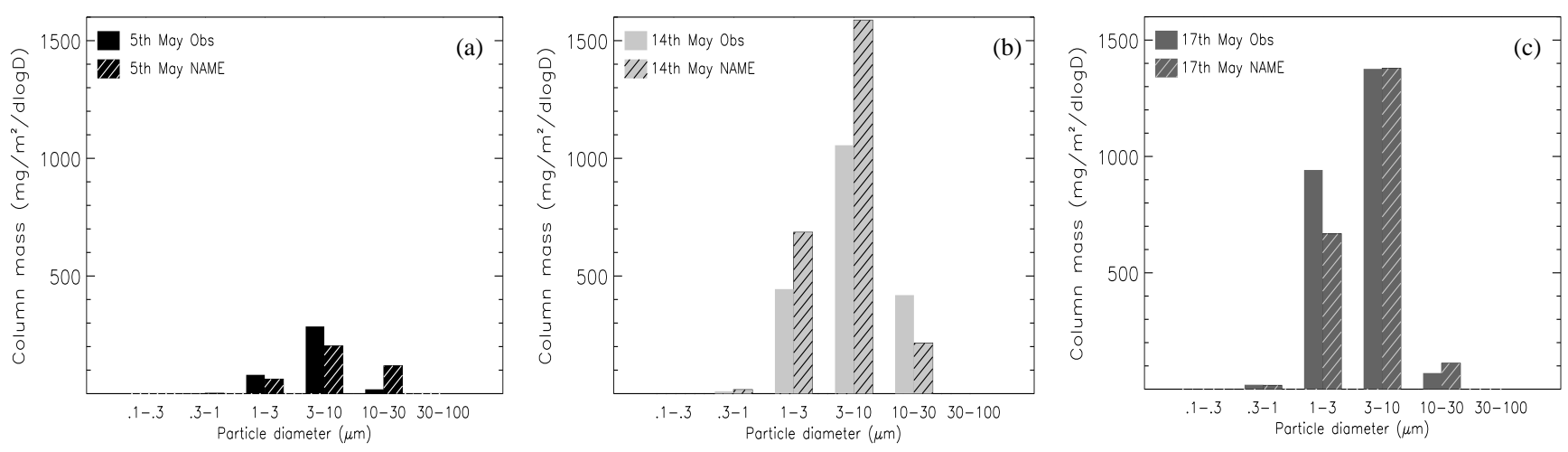

Fig. 6. Rebinned observed column-integrated mass (solid fill) and NAME column-integrated mass (striped fill) using distal particle size distribution 2. (a) 12:00 UTC on 5 May, (b) 13:00 UTC on 14 May and (c) 15:00 UTC on 17 May.

other aerosols and clouds. The specific ash signature depends on the mineral composition and the particle size distribution. A method for detecting ash from high-resolution infrared sounders proposed by Clarisse et al. (2010) has been applied to produce this figure. Measurements have been quantified using an ash absorption index (brightness temperature difference between $1168 \mathrm{~cm}^{-1}$ and $1231.5 \mathrm{~cm}^{-1}$ ) for measurements which pass the ash detection test (and 0 for those that do not).

\subsubsection{May}

On 5 May, Fig. 7a to c, a high pressure system was located to the west of the UK in the North Atlantic. Ash emitted from the volcano in Iceland was transported in an anticyclonic direction around the high pressure system. On this day the ash cloud was transported directly from Iceland to the UK. Note that on this day the widespread presence of cloud in the region prevented the detection of the majority of the ash cloud (there was a small gap in the cloud over Ireland). It is difficult to draw a conclusion about the accuracy of the ash cloud location based on the IASI measurements. However, assuming that the ash and $\mathrm{SO}_{2}$ are co-located, the ash cloud position compares well with the GOME-2 $\mathrm{SO}_{2}$ total column observations on 5 May (http://atmos.caf.dlr.de/gome/product_so2. html). The horizontal extent of the modelled ash cloud increases as the ash is transported away from the volcano. Generally, the column-integrated mass decreases both with distance from a maximum along the central ash cloud axis and with distance from the volcano (Fig. 7b), although there is a second peak in column-integrated mass located over Ireland. Figure $7 \mathrm{c}$ shows the average age of the ash cloud at the height at which the maximum concentration in the column occurs. The age of the ash cloud represents the mean age of ash in a $12 \mathrm{~km}$ by $12 \mathrm{~km}$ grid box. The mean age of the ash cloud increases with distance travelled from the volcano, as expected. In Fig. $7 b$ and $c$ the black cross shows the location of the aircraft vertical profile. On this day the aircraft observations were taken close to the central ash cloud axis. The NAME simulated ash at this location had an average age of $28 \mathrm{~h}$. The observed column-integrated mass was $197 \mathrm{mg} \mathrm{m}^{-2}$. Figure 8 shows that the plume height $28 \mathrm{~h}$ prior to the observation was between 4.5 and $6 \mathrm{~km}$ a.s.l.

\subsubsection{May}

Between 12 and 14 May a low pressure system passed over Iceland travelling from the north-west. This resulted in ash transport to the north and west of Iceland on 12 May as it was advected cyclonically around the low; towards Europe on 13 May and finally to the west of Iceland on 14 May. The location of the volcanic ash cloud both to the west of Iceland and extending in a south-easterly direction covering western Scotland and north-west England is in good agreement with the IASI detected ash cloud, Fig. $7 \mathrm{~d}$ and e. There was relatively little cloud cover at this time. Ash released on 14 May is aged between 0 and $24 \mathrm{~h}$ and has high values of columnintegrated mass due to an increase in mass eruption rate, corresponding to an increase in plume height from 6.5 to $9 \mathrm{~km}$, that occurred on 13 May (Fig. 8). The aircraft observations on 14 May were taken close to the central ash cloud axis in a region in which the ash had travelled for an average of $26 \mathrm{~h}$ from the volcano. The observed column-integrated mass was $969 \mathrm{mg} \mathrm{m}^{-2}$. The plume height $26 \mathrm{~h}$ prior to the observation time was between 6 and $6.5 \mathrm{~km}$ a.s.l. (Fig. 8).

\subsubsection{May}

On 17 May, Fig. $7 \mathrm{~g}$ to i, a high pressure system moved north towards Iceland from the Atlantic resulting in ash transport to the east and then south of Iceland, travelling anticyclonically around the high pressure centre. The location of the volcanic ash cloud over the North Sea and covering the eastern part of Scotland and north-east England is in good agreement with the IASI detected ash cloud. This ash is aged between 0 and $48 \mathrm{~h}$. The aircraft observations on 17 May were also taken close to the central ash cloud axis in a region in which the ash had travelled an average of $58 \mathrm{~h}$ 

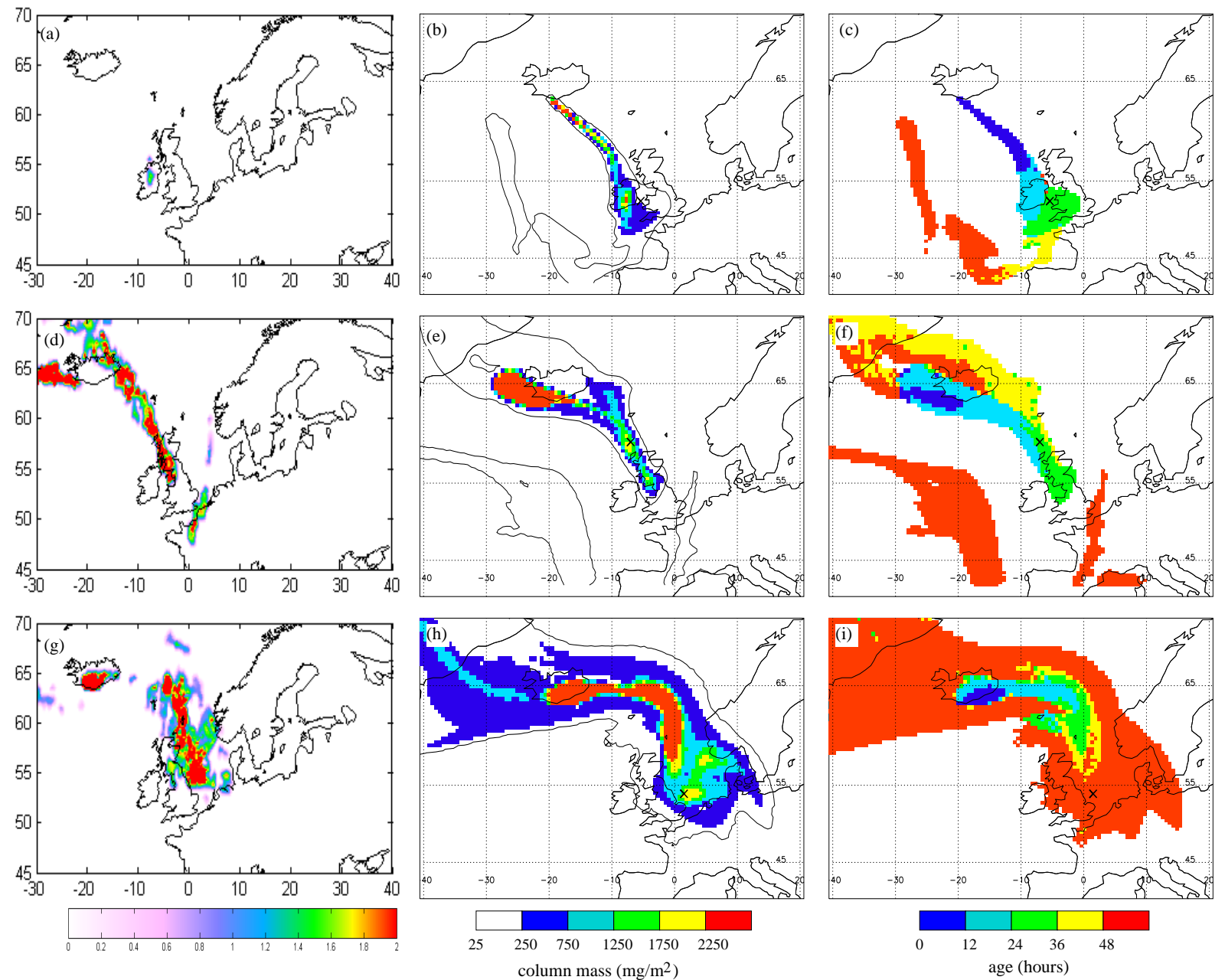

Fig. 7. (a), (d) and (g) IASI measured volcanic ash index (K) at (a) 10:35 UTC on 5 May, at (d) 10:49 UTC on 14 May, and at (g) 09:46 UTC on 17 May. (b), (e) and (h) Column-integrated mass using distal particle size distribution 2 and a distal fine ash fraction of $4.5 \%$. (c), (f) and (i) Average age of the ash cloud at the height at which the maximum concentration in the column occurs. (b) and (c) at 12:00 UTC on 5 May, (e) and (f) at 13:00 UTC on 14 May, and (h) and (i) at 15:00 UTC on 17 May. The cross shows the location of the aircraft observations.

from the volcano. The observed column-integrated mass was $1211 \mathrm{mg} \mathrm{m}^{-2}$. The plume height $58 \mathrm{~h}$ prior to the observation was approximately $6.5 \mathrm{~km}$ a.s.l. (Fig. 8).

\subsection{Variation of concentration of fine ash with travel time}

Some of the spatial variability in column-integrated mass shown in Fig. 7b, e and $h$ is due to the fluctuating mass eruption rate. In this section the NAME simulated age and mass fine ash concentrations have been calculated every $6 \mathrm{~h}$ during a 14 day period of the eruption (4-18 May). A normalised concentration scale, related to the source properties at the time that the ash was emitted from the volcano, is defined. The normalised fine ash concentration is calculated by dividing the fine ash concentrations by their respective source fine ash concentrations. This should remove most of the variability due to the time varying mass eruption rate. The source fine ash concentration, $Q$, is in kilogrammes per metre cubed and is calculated using Eq. (1):

$Q=M /(u \Delta y \Delta h)$,

where $M$ is the mass eruption rate in kilogrammes per second, $u$ is the horizontal wind speed at the mean height of the emission in metres per second, $\Delta y$ is the near-source crossplume width in metres, and $\Delta h$ is the vertical distribution of ash at the source, set at $1000 \mathrm{~m}$. In these NAME simulations $\Delta y$ is taken to be $5000 \mathrm{~m}$. An average of the normalised fine ash concentration in each column is then calculated over the depth of the layer. Finally, the maximum layer average normalised fine ash concentration is found for each age and $6 \mathrm{~h}$ time window. This represents the layer average normalised fine ash concentration at the centre of the ash cloud axis, hereafter termed normalised concentration. 


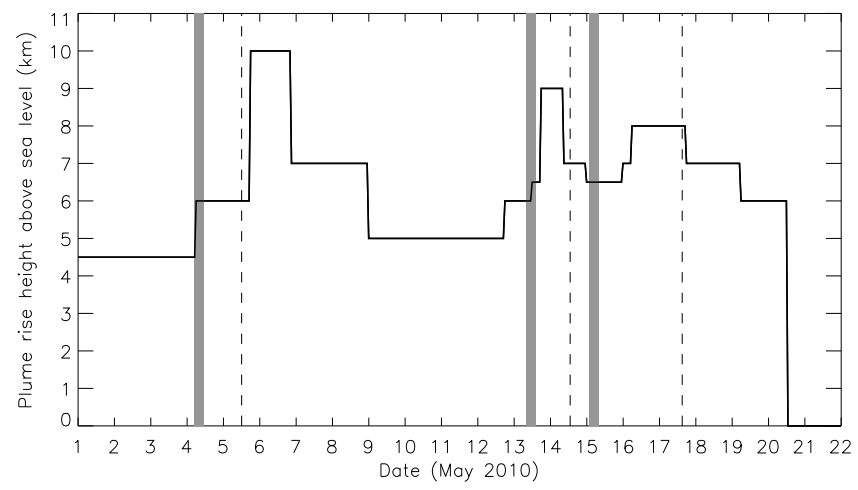

Fig. 8. Time series of the height of the eruption plume above sea level. The dashed lines represent the times at which the FAAM aircraft performed profiles through the ash cloud. The grey shading represents the approximate times that the observed ash particles were emitted from the volcano.

For each travel time, the mean and upper and lower quartiles, evaluated over the collection of 6 hourly results, were calculated and are shown in Fig. 9a along with the observed normalised fine ash concentrations as a function of age. The observed concentrations are normalised by dividing the observed concentrations by the source concentration at the time at which the ash was emitted from the volcano. For an assumed near-source cross-plume width of $5000 \mathrm{~m}$, the concentration drops to $35 \%$ of the source concentration in the first hour after emission from the volcano. This is a result of the rapid dispersion of ash by turbulent eddies represented in the model using parameterised diffusion, and due to the fact that concentrations in these NAME simulations are computed by summing the mass of ash particles in a $0.375^{\circ}$ latitude by $0.5625^{\circ}$ longitude box. (Note, that halving the assumed cross-plume width will result in a halving of the maximum normalised concentration). Between 6 and $72 \mathrm{~h}$ after emission the normalised fine ash concentration decreases at a rate that decreases with time. Thus the time to half the concentration gets longer with each successive halving. From $72 \mathrm{~h}$ onwards however, the normalised fine ash concentration also decreases due to deposition and increased spreading (figure 9(b)).

For the in-situ measurements on 5,14 and 17 May, the layer average ash age is estimated from the NAME model simulation. The observed range of normalised concentrations are calculated using the maximum and minimum observed concentrations in the vertical profile measurements shown in Fig. 3. Figure 9a also shows observed normalised maximum concentrations from lidar observations of the ash cloud (Grant et al., 2012, their figure 11). For the lidar observations, the range corresponds to the distribution of normalised concentrations calculated using the observed column maximum concentrations measured by the airborne lidar as it flew above the ash cloud, thus these values are likely to be overestimates. Both the model and observations show that after approximately $24 \mathrm{~h}$ travel time, changes in ash concentration are small. This suggests that within the distal ash cloud processes leading to the rapid loss of ash from the column, such as microphysical processes or deposition of large particles (not represented in NAME), are not as important as in the near-source region.

Schumann et al. (2010) measured ash concentrations of aged volcanic ash in the distal ash cloud and found that concentrations follow roughly an exponential decay law with half times of order 20 to $22 \mathrm{~h}$. However, their correlation was fairly weak, mainly because of the strong influence of the specific meteorological conditions. Rose et al. (2000) also found that masses of fine ash, as measured by satellite, decrease rapidly in the first $36 \mathrm{~h}$ and then decrease much more slowly. They concluded that as much as $75-90 \%$ of the fine ash falls out of volcanic clouds in the first $36 \mathrm{~h}$, and is deposited in ash blankets which they viewed as direct evidence for aggregation caused by interaction of volcanic ash particles with ice particles. However, direct evidence for ice in ash blankets is elusive. Due to the different nature of volcanic eruptions, it is difficult to make a direct comparison with the Rose et al. (2000) study. However, given that NAME does not include aggregation processes but also simulates a rapid decrease in concentration in the first $36 \mathrm{~h}$, this suggests that aggregation processes do not play an important role in the distal ash cloud for this eruption.

Disparity between the model and observed concentrations can be due to a wide variety of reasons. For example, the model relationship represents the evolution of the concentrations at the centre of the ash cloud, whereas the observations are from a variety of positions in the ash cloud. In addition, whilst the grey shading represents the models 2575 th percentile range, variability in the meteorological conditions can result in a much larger range of possible values. The observed values are very sensitive to the source concentration used to normalise the observed concentrations. A constant layer averaged age was assumed and used to estimate the emission time, and hence the source concentration. During periods in which the source emission rate varied rapidly, small changes in ash emission time can greatly change the source concentration. For example, on 16 May (analysed in Grant et al. (2012)), changing the emission time by $2 \mathrm{~h}$ resulted in a change in the range of normalised concentrations from $0.5 \times 10^{-5}-3 \times 10^{-5} \%$ to $0.24-1.28$ (figure 9 (a) dashdot line). This small time shift is possible due to the uncertainty in the plume location on 16 May. Finally, if the observations are more patchy and in thinner layers, this will lead to generally higher maximum concentrations.

If we assume that there are no processes leading to the loss of ash from the ash cloud then the inverse of the normalised concentration is proportional to the cross-sectional area $(\Delta y \times \Delta z)$ of the ash cloud. The instantaneous spread of the ash cloud, due to grid-box averaging, leads to an initial overestimation of the plume area and hence an underestimation of the normalised concentration. Between 1 and 

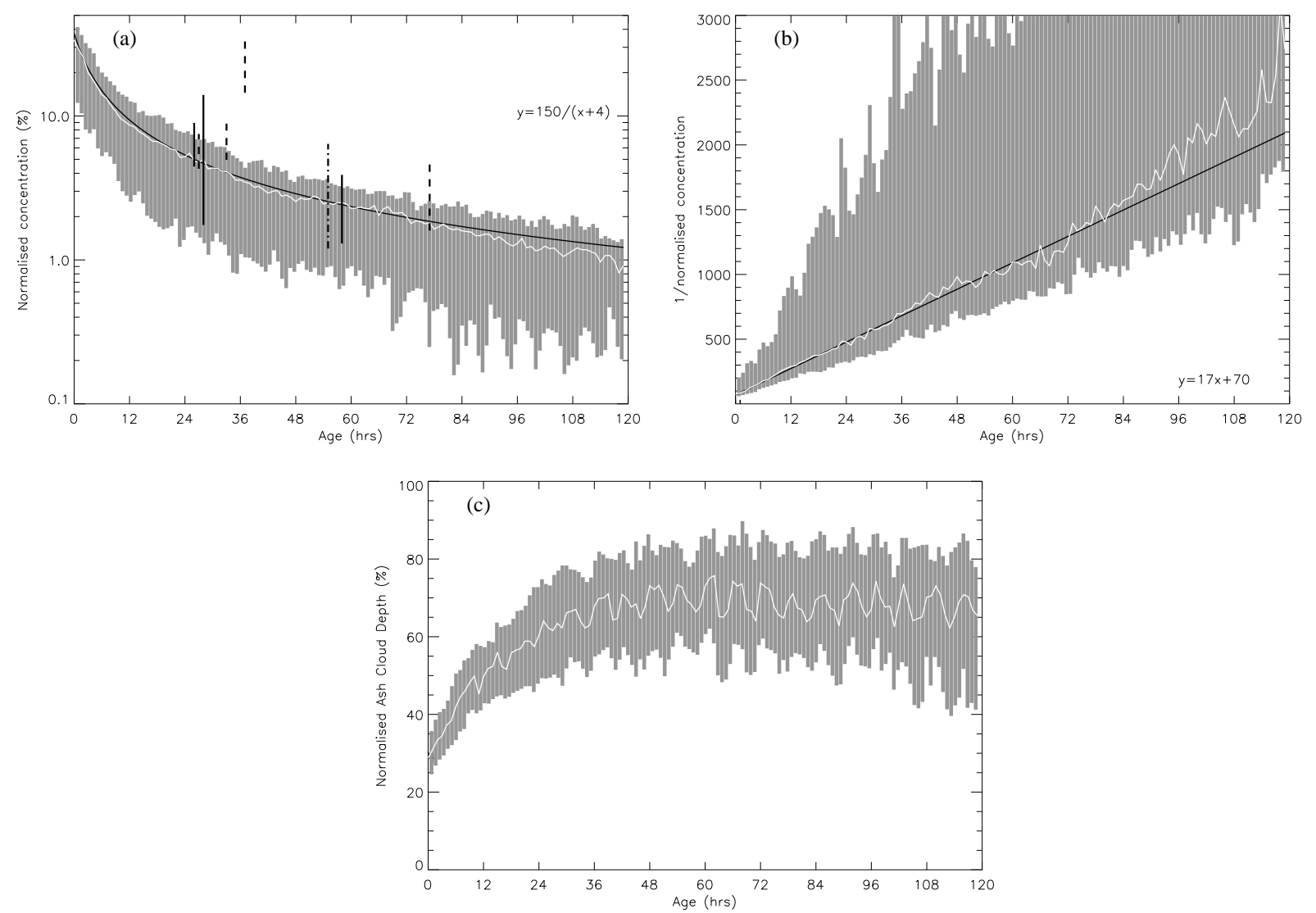

Fig. 9. Mean (solid white line) and 25-75th percentile (grey shading) of (a) NAME normalised concentration overlaid with observed normalised concentration as a function of travel time (in-situ measurements (solid), lidar measurements (dashed, dash-dot), fit to mean (solid black line and equation)), (b) 1/normalised concentration as a function of travel time (fit to mean (solid black line and equation)), and (c) normalised ash cloud depth as a function of travel time.

$72 \mathrm{~h}$ after emission, the ash cloud area increases linearly with time. This is consistent with the following argument: For diffusive growth (on scales bigger than the eddies causing the diffusion), we expect $\Delta y$ and $\Delta z$ to increase like the square root of time. Therefore, the net effect will be an increase in area that is proportional to time, as shown for the first $24 \mathrm{~h}$ after emission. At later times, when the ash cloud gets larger, the range of eddy sizes that contribute to its spreading increases. Therefore, we expect to see an acceleration in plume area with $\Delta y$ and $\Delta z$ increasing like time. Thus, the net effect would be an increase in area that is proportional to time squared. However, after $24 \mathrm{~h} \Delta z$ has stopped increasing due to the lower ground boundary; therefore the area continues to increase at a rate proportional to time until $72 \mathrm{~h}$ after emission. After this time, the assumption that loss of ash from the ash cloud is negligible is not valid (Fig. 9a). Thus, it appears that the evolution of the normalised concentration during this period can be explained by the geometric spreading of the ash cloud.
Figure 9c shows the normalised ash cloud depth. This is calculated by dividing the ash cloud depth (defined as the vertical extent of the concentrations with $>1 \%$ of the peak column concentration), at the location of maximum normalised concentration, by the height above sea level that the ash was released at the source. For the first $24 \mathrm{~h}$ the normalised ash cloud depth increases by $30-70 \%$ as the ash cloud spreads vertically via the sedimentation of large particles, large-scale ascent or descent and vertical diffusion. From $24 \mathrm{~h}$ onwards the normalised ash cloud depth remains fairly constant as the Earth's surface provides a lower bound to the plume vertical spreading.

\section{Particle size distribution}

In this section we analyse the spatial and temporal variability of the PSD at the location of the maximum column concentrations. First, we analyse the PSD for the simplest meteorological case on 5 May. Then, we extend this analysis to explain the variability on 14 and 17 May. 

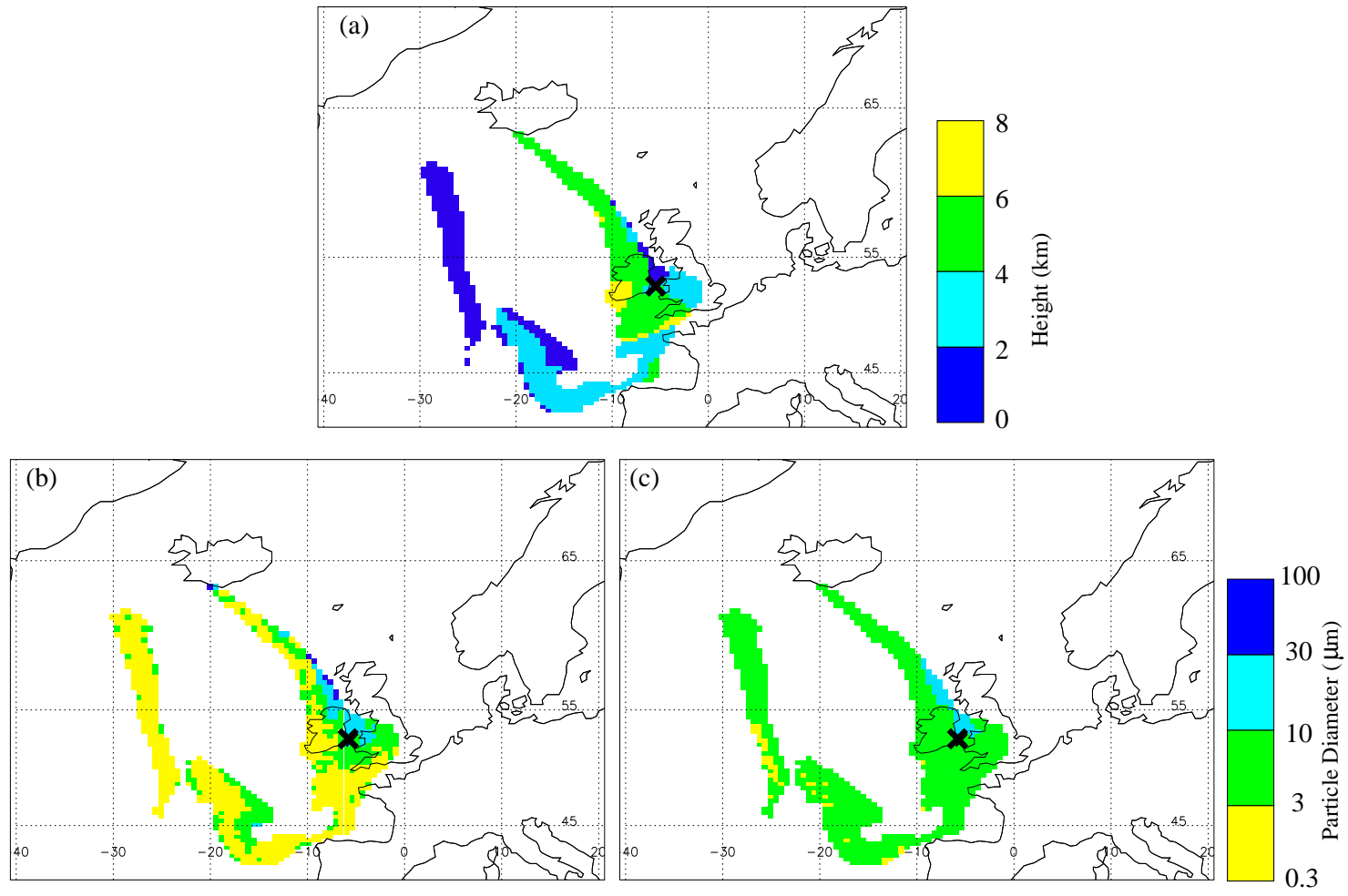

Fig. 10. (a) Height of the maximum mass concentration in each column. Mode of the particle size distribution at the height of the maximum mass concentration in NAME using (b) uniform distal particle size distribution 3 and (c) distal particle size distribution 2. 12:00 UTC on 5 May; the cross shows the location of the aircraft observations.

\subsection{Spatial variability in particle size distribution}

\subsubsection{May}

Figure 10a shows the height of the maximum concentration in the column at 12:00 UTC on 5 May. For travel times between 12 and $24 \mathrm{~h}$, Fig. $7 \mathrm{~b}$, the ash cloud is sloped from a height of less than $2 \mathrm{~km}$ along the north-east edge of the ash cloud to a height of greater than $6 \mathrm{~km}$ along the south-west edge of the ash cloud. Further from the volcano (for ash with travel times greater than $36 \mathrm{~h}$ ), the height of the ash cloud descends from $4 \mathrm{~km}$ to less than $2 \mathrm{~km}$ as it travels anticyclonically around the high pressure region in the North Atlantic.

A NAME simulation was performed in which a uniform DPSD was used (DPSD 3 in Table 1). Figure 10b shows the mode of the PSD at the height of the maximum normalised concentration in the column at 12:00 UTC on 5 May. The PSD in the highest part of the sloped ash cloud has its mode between 0.3 and $3 \mu \mathrm{m}$ diameter, whereas in the lowest part of the sloped ash cloud the particle size distribution has its mode between 10 and $30 \mu \mathrm{m}$ diameter. This is consistent with the idea that vertical wind shear combined with differential sedimentation of large and small ash particles has separated out the large and small particles, spatially leading to variability in the column-integrated PSD. Further from the volcano vent the mode of the PSDs moves towards smaller diameter size bins, reflecting the deposition of larger ash particles to the surface.

When the same analysis is performed for a simulation in which DPSD 2 is used at the source, Fig. 10c, most of the spatial variability in the mode of the PSD disappears. In the majority of the ash cloud, the mode, influenced by the DPSD, remains between 3 and $10 \mu \mathrm{m}$, and thus the effects of sedimentation and vertical wind shear are masked by the DPSD.

The aircraft profile was taken close to the centre of the ash cloud where the PSD has its mode in the $3-10 \mu \mathrm{m}$ diameter particle size bin but in a region of vertical wind shear. If the observations had been taken further north-east, the NAME simulation suggests that the PSD would have contained a larger percentage of larger diameter particles due to the combined effects of sedimentation and wind shear. Similarly if the observations had been taken further south-west the PSD would have contained a larger percentage of small diameter particles.

\subsubsection{5, 14 and 17 May}

In NAME the sedimentation rates for different sized particles are prescribed. Thus, we can calculate the average travel time from the volcano for different sized particles in DPSD 2 and can therefore estimate the effect that sedimentation, on its own, has on the PSD as it travels from the volcano 

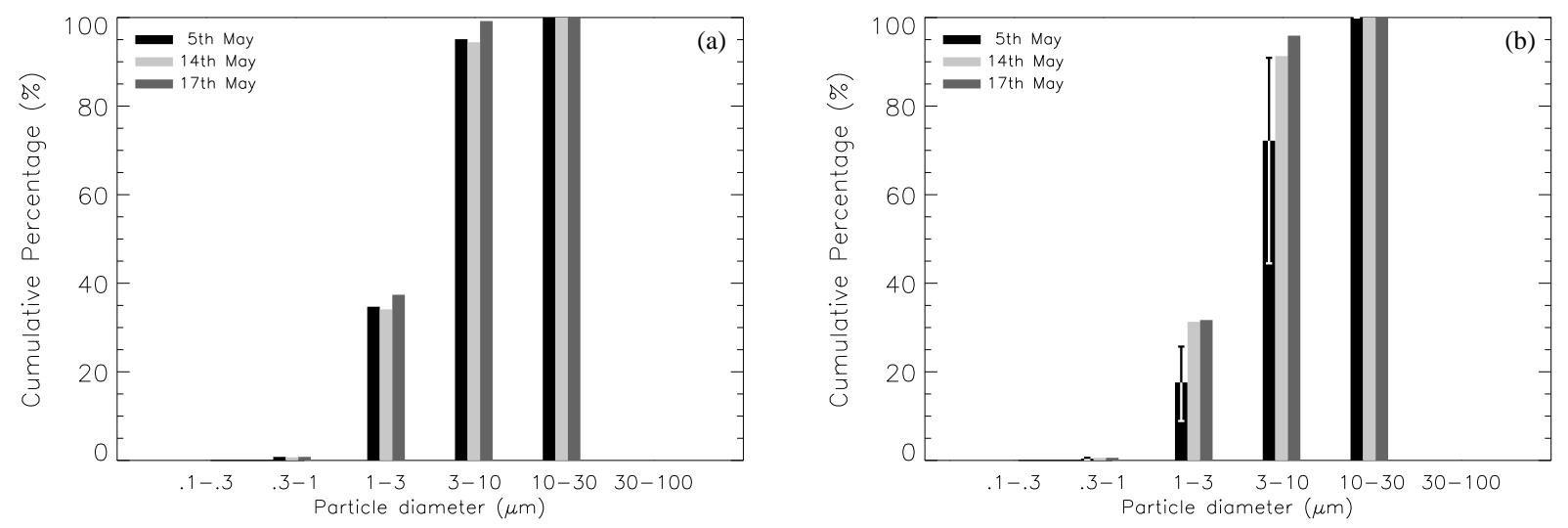

Fig. 11. Modelled column-integrated particle size distribution. (a) Due to sedimentation of particles only from NAME travel times and simple sedimentation model and (b) due to sedimentation and 3-D transport from NAME. At the location of the aircraft observation at 12:00 UTC on 5 May (dashed), 13:00 UTC on 14 May (dotted) and 15:00 UTC on 17 May (solid). The error bars represent the range of particle size distributions simulated by NAME, at the location of the aircraft observation on 5 May, if the ash cloud is shifted 1 degree north (bottom range) or south (top range).

to the observation location. Figure 11a shows the cumulative percentage of column-integrated mass carried by different sized particles for the three observed cases when the effects of sedimentation only are taken into account. On 5 and 14 May the distributions are almost identical, as expected, since the average travel times are very similar, $28 \mathrm{~h}$ and $26 \mathrm{~h}$, respectively. The distribution on 17 May however contains a much smaller percentage of mass carried by particles with diameters greater than $10 \mu \mathrm{m}(<2 \%)$, reflecting the longer average travel time of $58 \mathrm{~h}$. Thus, almost all of the large particles have been deposited to the surface. Figure $11 \mathrm{~b}$ shows the percentage of mass carried by different sized particles for the three observed cases when the effects of sedimentation and transport by the 3-D winds are taken into account. The distribution on the 5th is now different. 3-D transport has a negligible effect on the particle size distribution on 14 and 17 May. However, on 5 May the effects of sedimentation and 3-D transport (namely vertical wind shear) are greater and result in a higher percentage of modelled mass carried by particles with diameters greater than $10 \mu \mathrm{m}$ to the observation location. This result is inconsistent with the observations in Fig. 2b, which show that the observations on 14 May contain a higher percentage of particles with diameters greater than $10 \mu \mathrm{m}$ compared to 5 May observations. However, given the strong effect of vertical wind shear on 5 May (Fig. 10b), the NAME simulated PSD is very sensitive to the exact location of the ash cloud. Figure 11b shows that shifting the ash cloud 1 degree to the north (south) produces a PSD with a much larger (smaller) percentage of particles with diameters greater than $10 \mu \mathrm{m}$. Ash cloud location errors of this magnitude have been shown to exist by Dacre et al. (2011).

\subsection{Temporal variability in particle size distribution}

As for the concentration, much of the spatial variability in the column-integrated PSD is due to the transport by the 3-D winds. In this section the NAME simulated average age and column-integrated PSDs have been analysed in the whole domain every $6 \mathrm{~h}$ during a 14 day period of the eruption (418 May). Averaging over a range of synoptic conditions reduces the variability due to the 3-D transport. Figures $12 \mathrm{a}-$ $\mathrm{d}$ show how the total column-integrated PSD changes with travel time. The percentage of the column-integrated mass in the $0.3-1 \mu \mathrm{m}, 1-3 \mu \mathrm{m}$ and 3-10 $\mu \mathrm{m}$ diameter particle size bins increases with time, balancing the decrease in the percentage of mass in the 10-30 $\mu \mathrm{m}$ diameter particle size bin. Initially, during the first $24 \mathrm{~h}$ after emission from the volcano, the percentage of the column-integrated mass carried by 10 $30 \mu \mathrm{m}$ diameter particles decreases rapidly. This is a result of a higher range of sedimentation rates, resulting in vertical spreading of these particles (Fig. 12e). The 10-30 $\mu \mathrm{m}$ diameter particles are distributed over a greater vertical depth than the 1-3 $\mu \mathrm{m}$ and 3-10 $\mu \mathrm{m}$ diameter particles, and thus are subject to a greater degree of wind shear. Between 24 and $72 \mathrm{~h}$ after emission, the PSD does not change much as it travels. After $72 \mathrm{~h}$ the $10-30 \mu \mathrm{m}$ diameter particles are deposited to the surface, resulting in a shift in the particle size distribution to smaller particle sizes.

\section{Conclusions}

The Eyjafjallajökull volcano in Iceland erupted for 21 days during April and May 2010 emitting large amounts of ash into the atmosphere. Over the UK the ash cloud from Eyjafjallajökull was observed on several occasions by the FAAM BAe-146 aircraft. The aircraft was equipped with in-situ 


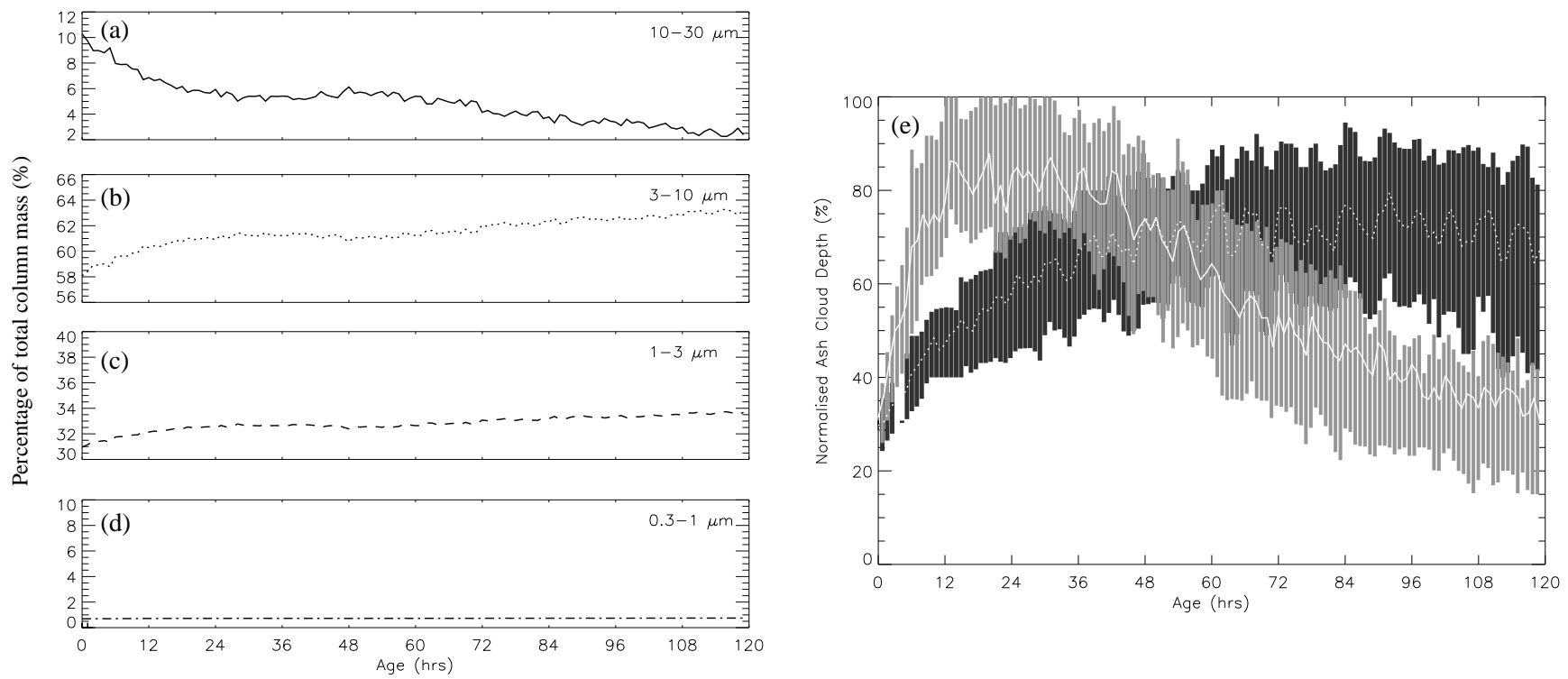

Fig. 12. (a) Mean percentage of total column-integrated mass carried by (a) 10-30 $\mu \mathrm{m}$ diameter particles, (b) 3-10 $\mu \mathrm{m}$ particles, (c) $1-3 \mu \mathrm{m}$ diameter particles and (d) 0.3-1 $\mu \mathrm{m}$ diameter particles. (e) Mean and 25-75th percentile of normalised ash cloud depth for 10-30 $\mu \mathrm{m}$ diameter particles (solid line, light grey shading) and 1-3 $\mu \mathrm{m}$ diameter particles (dotted line, dark grey shading).

particle measuring probes which measured the concentration of volcanic ash carried by particles of varying sizes. These observations have been used to evaluate both the columnintegrated mass and PSD from the UK Met Office dispersion model, NAME. The NAME model has also been used to investigate the general dispersion characteristics of volcanic ash.

Quantitative comparison of the observed and NAME simulated column-integrated masses at three different locations suggests that between 2-6\% of the total emitted mass is transported long distances by small $(<30 \mu \mathrm{m}$ diameter $)$ ash particles. This is consistent with the results of Dacre et al. (2011), who compared NAME concentrations to groundbased lidar estimates for an earlier stage of the eruption, and with the results of Grant et al. (2012) when compared with estimates from an airborne lidar. NAME is also able to simulate the observed column-integrated particle size distribution (PSD) if a distal particle size distribution (DPSD) containing a large fraction of $<10 \mu \mathrm{m}$ diameter particles is used. This suggests that Eyjafjallajökull emitted particles that were particularly fine, possibly due to the interaction of volcanic ash with the ice cap (Gislason et al., 2011).

By normalising temporal variations in the mass eruption rate and averaging over a range of synoptic conditions, the factors controlling the evolution of the fine ash concentration and column-integrated PSD at the centre of the distal ash cloud were determined. Figure 13 summarises the main processes occurring in the distal ash cloud for the Eyjafjallajökull tropospheric eruption.

- Between 6 and $24 \mathrm{~h}$ after emission from the volcano, the fine ash concentration at the centre of the ash cloud de- creases due to horizontal dispersion, and the depth of the ash cloud increases by $50 \%$ due to sedimentation of 10 $30 \mu \mathrm{m}$ diameter particles. The column-integrated PSD includes an increasing fraction of $<10 \mu \mathrm{m}$ particles as the $10-30 \mu \mathrm{m}$ particles are dispersed more widely due to their increased exposure to wind shear.

- Between 24 and $72 \mathrm{~h}$ after emission from the volcano, the fine ash concentration at the centre of the ash cloud again decreases due to horizontal dispersion, but the depth of the ash cloud only increases by $10 \%$ due to the bounding limit of the Earth's surface. The PSD remains fairly constant.

- Between 72 and $120 \mathrm{~h}$ after emission from the volcano, the fine ash concentration at the centre of the ash cloud decreases and the column-integrated PSD includes an increasing fraction of $<10 \mu \mathrm{m}$ particles due to the combined effect of horizontal dispersion and deposition of 10-30 $\mu \mathrm{m}$ diameter particles to the surface.

Acknowledgements. The authors would like to acknowledge David Thomson at the Met Office for his insightful comments on the paper. We thank the University of Manchester, who supplied CAS data from the FAAM aircraft, and L. Clarisse at F.R.S.-FNRS, who supplied the IASI data. IASI has been developed and built under the responsibility of the Centre National d'Etudes Spatiales (CNES, France). It is flown on-board the Metop satellites as part of the EUMETSAT Polar System. Airborne data were obtained using the BAe-146-301 Atmospheric Research Aircraft flown by Directflight Ltd and managed by the Facility for Airborne Atmospheric Measurements (FAAM), which is a joint entity of the Natural 


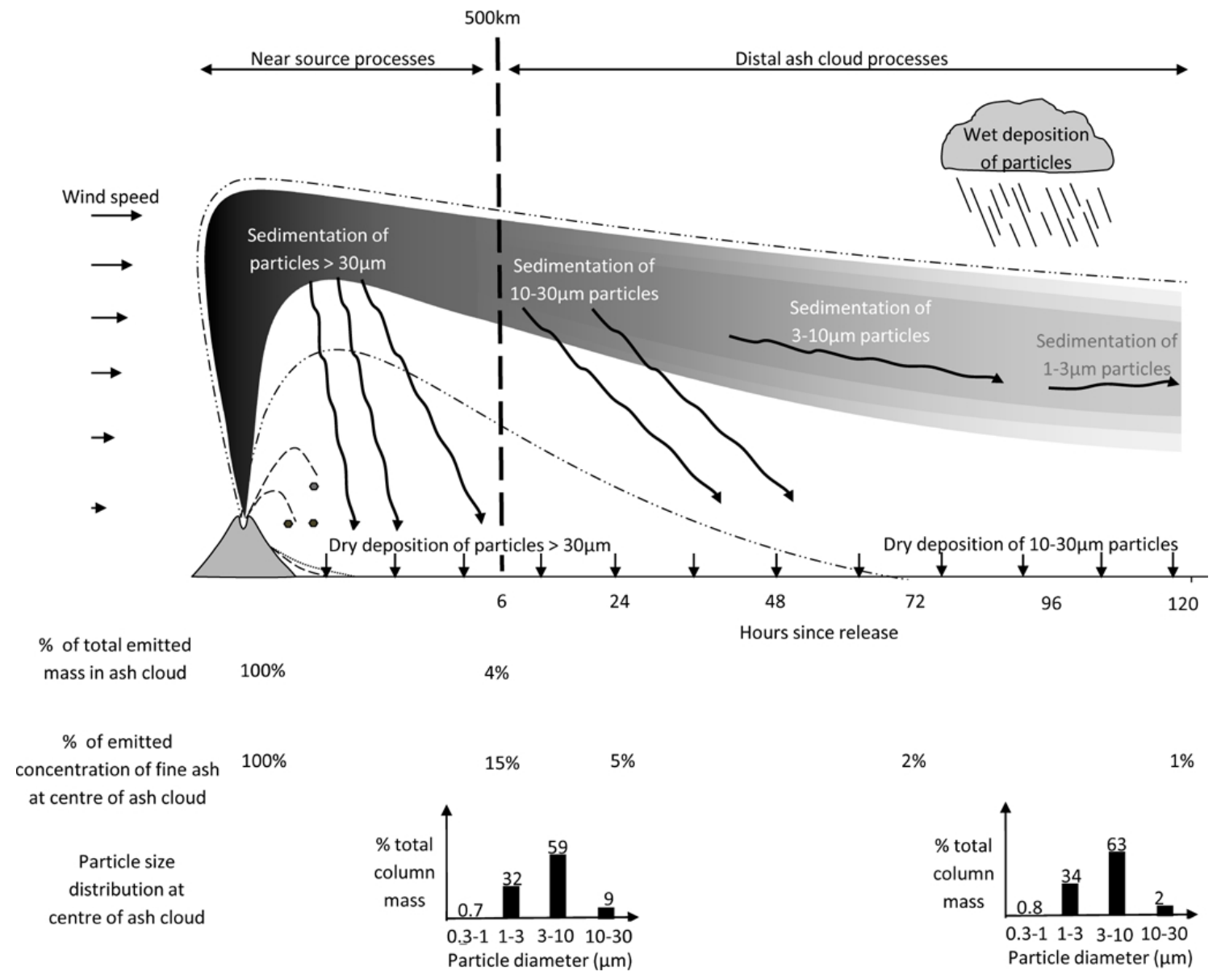

Fig. 13. Schematic showing the processes controlling the evolution of the fine ash concentration and particle size distribution in the distal ash cloud for the Eyjafjallajökull tropospheric eruption. The grey shadings represent the fine ash concentration, with $1 \%$ peak column concentrations represented by dash-dot contour. Fine ash refers to small particles $(<30 \mu \mathrm{m}$ diameter $)$. Note that, for other eruptions, the fine ash concentration and particle size distributions are likely to depend on the magnitude of the eruption.

Environment Research Council (NERC) and the Met Office. Alan Grant was funded by a National Centre for Atmospheric Science (NCAS) national capability grant.

Edited by: C. Bay Hasager

\section{References}

Ansmann, A., Tesche, M., Seifert, P., Groß, S., Freudenthaler, V., Apituley, A., Wilson, K. M., Serikov, I., Linné, H., Heinold, B., Hiebsch, A., Schnell, F., Schmidt, J., Mattis, I., Wandinger, U., and Wiegner, M.: Ash and fine-mode particle mass profiles from EARLINET-AERONET observations over central Europe after the eruptions of the Eyjafjallajökull volcano in 2010, J. Geophys. Res., 116, D00U02, doi:10.1029/2010JD015567, 2011.

Arason, P., Petersen, G. N., and Bjornsson, H.: Observations of the altitude of the volcanic plume during the eruption of Eyjafjallajökull, April-May 2010, Earth Syst. Sci. Data, 3, 9-17, doi:10.5194/essd-3-9-2011, 2011.
Bonadonna, C. and Houghton, B. F.: Total grain-size distribution and volume of tephra-fall deposits, Bull. Volcanol., 67, 441-456, doi:10.1007/s00445-004-0386-2, 2005.

Clarisse, L., Prata, F., Lacour, J.-L., Hurtmans, D., Clerbaux, C., and Coheur, P.-F.: A correlation method for volcanic ash detection using hyperspectral infrared measurements, Geophys. Res. Lett., 37, L19806, doi:10.1029/2010GL044828, 2010.

Dacre, H. F., Grant, A. L. M., Hogan, R. J., Belcher, S. E., Thomson, D. J., Devenish, B., Marenco, F., Hort, M. C., Haywoood, J. M., Ansmann, A., Mattis, I., and Clarisse, L.: Evaluating the structure and magnitude of the ash plume during the initial phase of the 2010 Eyjafjallajökull eruption using lidar observations and NAME simulations, J. Geophys. Res., 116, D00U03, doi:10.1029/2011JD015608, 2011.

Daniele, P., Lirer, L., Petrosino, P., Spinelli, N., and Peterson, R.: Applications of the PUFF model to forecasts of volcanic clouds dispersal from Etna and Vesuvio, Comput. Geosci., 35, 10351049, doi:10.1016/j.cageo.2008.06.002, 2009.

Dellino, P., Gudmundsson, M. T., Larsen, G., Mele, D., Stevenson, J. A., Thordarson, T., and Zimanowski, B.: Ash from the Eyjafjallajökull eruption (Iceland): Fragmentation processes 
and aerodynamic behavior, J. Geophys. Res., 117, B00C04, doi:10.1029/2011JB008726, 2012.

Devenish, B. J., Thomson, D. J., Marenco, F., Leadbetter, S. J., Ricketts, H., and Dacre, H. F.: A study of the arrival over the United Kingdom in April 2010 of the Eyjafjallajökull ash cloud using ground-based lidar and numerical simulations, Atmos. Environ., 48, 152-164, 2011.

European Commission: Volcano crisis report, available online at: http://ec.europa.eu/transport/ash_cloud_crisis_en.htm., last access: January 2012.

Gislason, S. R., Hassenkam, T., Nedel, S., Bovet, N., Eiriksdottir, E. S., Alfredsson, H. A., Hem, C. P., Balogh, Z. I., Dideriksen, K., Oskarsson, N., Sigfusson, B., Larsen, G., and Stipp, S. L. S.: Characterization of Eyjafjallajökull volcanic ash particles and a protocol for rapid risk assessment, P. Natl. Acad. Sci. USA, 108, 7307-7312, 2011.

Grant, A. L. M., Dacre, H. F., Thomson, D. J., and Marenco, F.: Horizontal and vertical structure of the Eyjafjallajökull ash cloud over the UK: a comparison of airborne lidar observations and simulations, Atmos. Chem. Phys., 12, 10145-10159, doi:10.5194/acp-12-10145-2012, 2012.

Hobbs, P. V., Radke, L. F., Lyons, J. H., Ferek, R. J., and Coffman, D. J.: Airborne measurements of particle and gas emissions from the 1990 volcanic eruptions of Mount Redoubt, J. Geophys. Res., 96, 18735-18752, 1991.

Horwell, C. J.: Grain-size analysis of volcanic ash for the rapid assessment of respiratory health hazard, J. Environ. Monit., 9, 1107-1115, doi:10.1039/b710583p, 2007.

Ilyinskaya, E., Tsanev, V. I., Martin, R. S., Oppenheimer, C., Le Blond, J., Sawyer, G. M., and Gudmundsson, M. T.: Near-source observations of aerosol size distributions in the eruptive plumes from Eyjafjallajökull volcano, March-April 2010, Atmos. Environ., 45, 3210-3216, 2011.

Johnson, B. T., Turnbull, K. F., Dorsey, J., Baran, A. K., Ulanowski, Z., Hesse, E., Cotton, R., Brown, P. R. A., Burgess, R., Capes, G., Webster, H. N., Woolley, A. M., Rosenberg, P. D., and Haywood, J. M.: In-situ observations of volcanic ash clouds from the FAAM aircraft during the eruption of Eyjafjallajökull in 2010, J. Geophys. Res., 117, D00U24, doi:10.1029/2011JD016760, 2011.

Jones, A., Thomson, D., Hort, M., and Devenish, B.: The UK Met Office's next-generation atmospheric dispersion model, in: NAME III. Air pollution modeling and its application XVII, edited by: Borrego, C. and Norman, A.-L., 2007.

Kaminski, E., Tait, S., Ferrucci, F., Martet, M., Hirn, B., and Husson, P.: Estimation of ash injection in the atmosphere by basaltic volcanic plumes: The case of the Eyjafjallajökull 2010 eruption, J. Geophys. Res., 116, B00C02, doi:10.1029/2011JB008297, 2011.

Kratzmann, D. J., Carey, S. N., Fero, J., Scasso, R. A., and Naranjo, J.-A.: Simulations of tephra dispersal from the 1991 explosive eruptions of Hudson volcano, Chile, J. Volcanol. Geoth. Res., 190, 337-352, 2010.

Kristiansen, N. I., Stohl, A., Prata, A. J., Bukowiecki, N., Dacre, H., Eckhardt, S., Henne, S., Hort, M. C., Johnson, B. T., Marenco, F., Neninger, B., Reitebuch, O., Seibert, P., Thomson, D. J., Webster, H. N., and Weinzierl, B.: Performance assessment of a volcanic ash transport model mini-ensemble used for inverse modeling of the 2010 Eyjafjallajökull eruption, J. Geophys. Res., 117, D00U11, doi:10.1029/2011JD016844, 2012.
Leadbetter, S. J. and Hort, M. C.: Volcanic ash hazard climatology for an eruption of Hekla Volcano, Iceland, J. Geophys. Res., 199, 230-241, 2011.

Mastin, L. G., Guffanti, M., Servrancks, R., Webley, P., Barsotti, S., Dean, K., Durnat, A., Ewert, J. W., Neri, A., Rose, W. I., Schneider, D., Siebert, L., Stunder, B., Swanson, G., Tupper, A., Volentik, A., and Waythomas, C. F.: A multidisciplinary effort to assign realistic source parameters to models of volcanic ash-cloud transport and dispersion during eruptions, J. Volcanol. Geoth. Res., 186, 10-21, 2009.

Rose, W. I., Bluth, G. J. S., and Ernst, G. G. J.: Integrating retrievals of volcanic cloud characteristics from satellite remote sensors: a summary, Phil. Trans. R. Soc. Lond. A, 358, 1585-1606, 2000.

Rust, A. C. and Cashman, K. V.: Permeability controls on expansion and size distribution of pyroclasts, J. Volcanol. Geoth. Res., 116, B11202, doi:10.1029/2011JB008494, 2011.

Scasso, R. A., Corbella, H., and Tiberi, P.: Sedimentological analysis of the tephra from the 12-15 August 1991 eruption of Hudson volcano, Bull. Volcanol., 56, 121-132, 1994.

Schumann, U., Weinzierl, B., Reitebuch, O., Schlager, H., Minikin, A., Forster, C., Baumann, R., Sailer, T., Graf, K., Mannstein, H., Voigt, C., Rahm, S., Simmet, R., Scheibe, M., Lichtenstern, M., Stock, P., Rüba, H., Schäuble, D., Tafferner, A., Rautenhaus, M., Gerz, T., Ziereis, H., Krautstrunk, M., Mallaun, C., Gayet, J.F., Lieke, K., Kandler, K., Ebert, M., Weinbruch, S., Stohl, A., Gasteiger, J., Groß, S., Freudenthaler, V., Wiegner, M., Ansmann, A., Tesche, M., Olafsson, H., and Sturm, K.: Airborne observations of the Eyjafjalla volcano ash cloud over Europe during air space closure in April and May 2010, Atmos. Chem. Phys., 11, 2245-2279, doi:10.5194/acp-11-2245-2011, 2011.

Scollo, S., Folch, A., and Costa, A.: A parametric and comparative study of different tephra fallout models, J. Volcanol. Geoth. Res., 176, 199-211, 2008.

Sparks, R. S. J., Bursik, M., Carey, S. N., Gilbert, J. A., Glaze, L. S., Sigurdsson, H., and Woods, A. W.: Volcanic Plumes, John Wiley and Sons, Chichester, 1997.

Stohl, A., Prata, A. J., Eckhardt, S., Clarisse, L., Durant, A., Henne, S., Kristiansen, N. I., Minikin, A., Schumann, U., Seibert, P., Stebel, K., Thomas, H. E., Thorsteinsson, T., Tørseth, K., and Weinzierl, B.: Determination of time- and height-resolved volcanic ash emissions and their use for quantitative ash dispersion modeling: the 2010 Eyjafjallajökull eruption, Atmos. Chem. Phys., 11, 4333-4351, doi:10.5194/acp-11-4333-2011, 2011.

Volentik, A. C. M., Bonadonna, C., Connora, C. B., Connora, L. J., and Rosic, M.: Modeling tephra dispersal in absence of wind: Insights from the climatic phase of the 2450 BP Plinian eruption of Pululagua volcano (Ecuador), J. Volcanol. Geoth. Res., 193, 117-136, 2010.

Webster, H. N., Thomson, D. J., Johnson, B. T., Heard, I. P. C., Turnbull, K. F., Marenco, F., Kristiansen, N. I., Dorsey, J. R., Minidin, A., Weinzierl, B., Schumann, U., Sparks, S. S. J., Loughlin, S. C., Hort, M., Leadbetter, S. J., Devenish, B., Manning, A. J., Witham, C., Haywood, J. M., and Golding, B.: Operational prediction of ash concentrations in the distal volcanic cloud from the 2010 eyjafjallajokull eruption, J. Geophys. Res., 117, D00U08, doi:10.1029/2011JD016790, 2012.

Wilson, L., Sparks, R., Huang, T., and Watkins, N.: The control of volcanic column heights by eruption energetics and dynamics, J. Geophys. Res., 83, 1829-1836, 1978. 